\title{
Utilization of Kinetic Isotope Effects for the Concentration of Tritium
}

\author{
Oak Ridge National Laboratory \\ The University of North Carolina at Chapel Hill \\ September 1997

\section{Progress Report}

\section{Principal Investigator}

Gilbert M. Brown

423-576-2756 (Phone)

423-574-4939 (Fax)

gbn@ornl.gov

Oak Ridge National Laboratory

P.O. Box 2008, MS 6119

Oak Ridge, TN 37831-6119

\section{Co-Investigator}

Thomas J. Meyer

919-962-6319 (Phone)

919-962-2388 (Fax)

tjmsec@net.unc.edu

University of North Carolina at Chapel Hill

Chapel Hill, NC 27599-3290

\section{Contributors}

C.-h. Ho, ORNL

L. Maya, ORNL

B. A. Moyer, ORNL

F. V. Sloop, ORNL

Paul Adams, UNC

R. A. Binstead, UNC

Chris Hartshorn, UNC

E. L. Lebeau, UNC 


\section{Research Objective}

The objective of this research program is to develop methods for-concentrating tritium in water based on large primary isotope effects in catalytic redox processes. Basic research is being conducted to develop the chemistry of a complete cyclic process. Because tritium [generally present as tritiated water (HTO)] is in a rapidly established equilibrium with water, it moves with groundwater and separation from water cannot be achieved by the usual pump-and-treat methods using sorbents. The general methodology developed in this work will be applicable to a number of U.S. Department of Energy waste streams, and as a consequence of the process, tritium could be incorporated in an organic polymer, a form that will prevent its ready transport in groundwater.

\section{Research Statement}

We will develop a process to remove tritium from $\mathrm{H}_{2} \mathrm{O}$ by concentrating it with respect to $\mathrm{H}_{2} \mathrm{O}$. Research will involve developing chemical cycles that produce high concentration factors for $\mathrm{HTO}$ and $\mathrm{T}_{2} \mathrm{O}$ based on the discrimination of $\mathrm{C}-\mathrm{H}$ and $\mathrm{C}-\mathrm{T}$ bonds in oxidation reactions. Several steps are required in a cyclic process for the concentration of tritium in water. In the first step the tritium is incorporated in an organic compound. H-T discrimination occurs as the tritium-containing compound is oxidized in a step involving a transition metal oxidant. Strong primary kinetic isotope effects lead to the oxidation of $\mathrm{C}-\mathrm{H}$ bonds in preference to $\mathrm{C}-\mathrm{T}$ bonds, and this reaction leads to concentration of tritium in the organic compound. The reduced form of the transition metal compound can be reoxidized so that the oxidation step can be made catalytic.

T. J. Meyer and coworkers at the University of North Carolina have investigated the kinetics and mechanism of the oxidation of a number of organic substrates by selected ruthenium(IV) oxo complexes, and their work has revealed large, primary kinetic isotope effects. For example, the oxidation of benzyl alcohol by the complex $\left[(\mathrm{bpy})_{2}(\mathrm{py}) \mathrm{Ru}(\mathrm{O})\right]^{2+}$, where bpy is $2,2^{\prime}$-bipyridine and py is pyridine, had $\mathrm{k}(\mathrm{C}-\mathrm{H}) / \mathrm{k}(\mathrm{C}-\mathrm{D})$ of 50 while displaying no significant $\mathrm{H}_{2} \mathrm{O} / \mathrm{D}_{2} \mathrm{O}$ solvent isotope effect.

$$
\left[\mathrm{Ru}^{\mathrm{IV}}(\mathrm{bpy})_{2}(\mathrm{py})(\mathrm{O})\right]^{2+}+\mathrm{Ph}-\mathrm{CH}_{2}-\mathrm{OH} \rightarrow\left[\mathrm{Ru}^{\mathrm{I}}(\mathrm{bpy})_{2}(\mathrm{py})\left(\mathrm{OH}_{2}\right)\right]^{2+}+\mathrm{Ph}-\mathrm{CHO}
$$

The oxidation of formate anion by the $\mathrm{Ru}(\mathrm{IV})$ oxo complex had $k(\mathrm{C}-\mathrm{H}) / k(\mathrm{C}-\mathrm{D})=19 \pm 3$

$$
\left[\mathrm{Ru}^{\mathrm{NV}}(\mathrm{bpy})_{2}(\mathrm{py})(\mathrm{O})\right]^{2+}+\mathrm{HCO}_{2}^{-}+\mathrm{H}_{2} \mathrm{O} \rightarrow\left[\mathrm{Ru}^{\mathrm{II}}(\mathrm{bpy})_{2}(\mathrm{py})\left(\mathrm{OH}_{2}\right)\right]^{2+}+\mathrm{CO}_{2}(\mathrm{~g})+\mathrm{OH}^{-}
$$

Tritium kinetic isotope effects are unknown, but they are expected to be as high or higher than the deuterium effect. Our research program will be aimed at developing chemical cycles that produce high concentration factors for $\mathrm{HTO}$ and $\mathrm{T}_{2} \mathrm{O}$. From known rate constants in model reactions, concentration factors in the range 10-100 per cycle appear feasible. H-T discrimination occurs in the oxidation step in which the strong primary kinetic isotope effects lead to preferential oxidation of $\mathrm{C}-\mathrm{H}$ bonds whose products are readily removed from the unreacted $\mathrm{C}-\mathrm{T}$ compound. Because the reduced ruthenium complex may be easily regenerated to the active $\mathrm{Ru}(\mathrm{IV})$ oxo form in an electrochemical reaction, the oxidation of the organic substrate can be made catalytic. 
On the other side of the cycle, tritium in the form of $\mathrm{HTO}$ and $\mathrm{T}_{2} \mathrm{O}$ will be incorporated into the oxidized organic substrate in a reductive process, and thus the chemical cycle may be closed. An important part of this project will entail evaluating the chemistry for incorporation of tritium into organic substrates, preferably using an electrochemical reduction process that will involve HTO (or $\mathrm{T}_{2} \mathrm{O}$ ) as the source of tritium. In any event, the organic substrate will be the oxidized organic liberated in the $\mathrm{C}-\mathrm{I}-\mathrm{I} / \mathrm{C}-\mathrm{T}$ discrimination reaction so that the reaction in the organic species is also a catalytic process.

\section{Research Progress}

Initial experimentation will be directed toward demonstrating the individual steps required for the concentration of tritium in water. We want to evaluate C-I-I/C-T kinetic isotope effects in the oxidation of organic substrates for which a deuterium effect is known. Tritiated formic acid is commercially available, and work is in progress to measure the tritium isotope effect for the oxidation of formate anion to carbon dioxide. A second early research objective is to carry out a proof-of-principle "cold" experiment in which the catalytic oxidation of an organic compound will demonstrate the fractionation of the deuterated component in a mixture of organic compounds having deuterium and proton substituents at the reactive site.

In terms of more long-range goals, two additional themes have been explored. One is a continuing investigation of the magnitude of kinetic isotope effects to identify the most promising metal catalytic system. The second is to develop the catalytic chemistry in redox active films and membranes appropriate for device applications.

Tritium Kinetic Isotope Effect. The kinetics for oxidation of tritiated formate will, by necessity, be carried out at a tracer level of tritium, and thus the rate constants must be measured with $\mathrm{Ru}(\mathrm{IV})$ as the reagent in excess. Previous kinetic isotope effects with $\mathrm{Ru}(\mathrm{IV})$ oxidants have used an excess of the organic substrate.

In preliminary experiments, we have determined the kinetics of the oxidation of ${ }^{1} \mathrm{H}-$ and ${ }^{2} \mathrm{H}$ formate with $\left[\mathrm{Ru}(\mathrm{IV})(\text { terpy)(bpy)O }]^{2+}\right.$ using an excess of the $\mathrm{Ru}(\mathrm{IV})$ reagent. The kinetics of formate oxidation by the related $\mathrm{Ru}(\mathrm{IV})$ complex, $\left[\mathrm{Ru}(\mathrm{IV})(\mathrm{bpy})_{2}(\mathrm{py}) \mathrm{O}\right]^{2+}$, was observed by Roecker and Meyer (J. of Amer. Chem. Soc., 108: 4066,1986) to be pH dependent and indicative that the reactive species is the formate anion. The observed rate constants showed a negligible $\mathrm{pH}$ dependence in the $\mathrm{pH}$ range 5.0 to 9.0 . We have investigated the kinetics at $\mathrm{pH} 6.0$ at $25^{\circ} \mathrm{C}$ in a phosphate buffer adjusted to an ionic strength of around $1 \mathrm{M}$. The complex $\left[\mathrm{Ru}(\mathrm{IV})(\mathrm{terpy})(\mathrm{bpy}) \mathrm{O}^{2+}\right.$ was prepared by the method of Takeuchi, et al. (Inorg Chem., 24: 1845, 1984). We found it convenient to prepare the $\mathrm{Ru}(\mathrm{IV})$ complex by electrochemical oxidation of the $\mathrm{Ru}$ (II) aqua complex (three compartment cell, Pt working and counter electrodes) at $+0.80 \mathrm{~V}$ vs SCE reference electrode.

It was apparent that the rate of the self decomposition reaction of $[\mathrm{Ru}(\mathrm{IV})(\mathrm{terpy})(\mathrm{bpy}) \mathrm{O}]^{2+}$ was competitive with the rate of oxidation of formate anion under the conditions investigated. Using milli-molar concentrations of $\mathrm{Ru}(\mathrm{IV})$, the time scales for the self-decomposition and formate oxidation reactions were such that the rate constants for the two reactions were readily separated. However a determination of the rate constant for oxidation of ${ }^{2} \mathrm{H}$-formate required that the disappearance of $\mathrm{Ru}(\mathrm{IV})$ by self-decomposition be specifically accounted for.

The absorbance vs time data for the spontaneous decomposition of the $\mathrm{Ru}(\mathrm{IV})$ complex in the $\mathrm{pH} 6.0$ buffer at $25^{\circ} \mathrm{C}$ was independent of the initial $\mathrm{Ru}(\mathrm{IV})$ concentration in the range 1 to 
$3 \mathrm{mM}$, and the data were well fit by a first-order rate expression. The observed rate constant was $1.43 \times 10^{-5} \mathrm{sec}^{-1}$. The reaction of the $\mathrm{Ru}(\mathrm{IV})$ complex with ${ }^{1} \mathrm{H}$-formate was investigated with formate in the range $0.05 \mathrm{mM}$ to $0.1 \mathrm{mM}$ and $\mathrm{Ru}(\mathrm{IV})$ in the range $0.5 \mathrm{mM}$ to $3 \mathrm{mM}$. The calculated second-order rate constant was $3.85 \mathrm{M}^{-1} \mathrm{~s}^{-1}$, which is in good agreement with the value reported by Roecker and Meyer (J. of Amer. Chem. Soc., 109: 746, 1987) for oxidation of formate by $\left[\mathrm{Ru}(\mathrm{IV})(\mathrm{bpy})_{2} \text { (py)O }\right]^{2+}\left(4.2 \mathrm{M}^{-1} \mathrm{~s}^{-1}\right.$. The reaction of ${ }^{2} \mathrm{H}$-formate with the same $\mathrm{Ru}(\mathrm{IV})$ complex was also first-order with respect to both $\mathrm{Ru}(\mathrm{IV})$ and deutero-formate, and the calculated secondorder rate constant was $1.53 \times 10^{-1} \mathrm{M}^{-1} \mathrm{~s}^{-1}$.

Thus, the kinetic isotope effect $(\mathrm{k}(\mathrm{C}-\mathrm{H}) / \mathrm{k}(\mathrm{C}-\mathrm{D}))$ for oxidation of formate by $\left[\mathrm{Ru}(\mathrm{IV})\left(\right.\right.$ terpy)(bpy)O ${ }^{2+}$ is 25 , which is comparable to but larger than the ratio measured by Roecker and Meyer $\left(\mathrm{k}_{\mathrm{H}} / \mathrm{k}_{\mathrm{D}}=19\right)$. Tritiated formic acid has been ordered, and preparations are in progress to determine the tritium isotope effect. This isotope effect will be measured at the tracer level by measuring the rate of transfer of tritium from the formate anion to HTO.

Proof-of-Principle Isotope Separation. Attractive substrates for a "cold" demonstration involving the removal of deuterium from water include formic acid or a derivative of benzyl alcohol. The former is a particularly attractive substrate because the tritiated formate anion could be separated by ion exchange from the reaction mixture. There are reports in the literature that $\mathrm{CO}$, is reduced to formate at an indium electrode. In a preliminary investigation, we had difficulty in telling the difference in current density for reduction of $\mathrm{N}_{2}$ saturated electrolyte versus $\mathrm{CO}$, saturated electrolyte, indicating that hydrogen evolution will be occurring in competition with the desired reduction. The literature suggests that careful electrode surface preparation may, be required to get good current efficiency for reduction of $\mathrm{CO}$,

Incorporation of tritium (or deuterium) from HTO [or dilute heavy water (HDO)] in the $\mathrm{CH}_{2}$ - position of benzyl alcohol could possibly be accomplished by the electrochemical reduction of benzaldehyde, the latter of which is reported to be reduced in high yield by electrochemical reduction at a $\mathrm{Pb}$ electrode in a dilute sulfuric acid solution. For use in the separation of tritium, it is apparent that the levels of this isotope will never be high enough to incorporate more than one tritium per benzyl alcohol.

Therefore, we investigated the kinetic isotope effect for oxidation of the monodeuterated species, benzyi-a-d-alcohol. The latter was prepared by the reduction of the ${ }^{1} \mathrm{H}$-benzaldehyde with $\mathrm{LiAlD}_{4}(\mathrm{LAD})$ in ether, and the purity and isotopic content were determined by highperformance liquid chromatography and gas chromatography/mass spectrometry respectively. The kinetic isotope effect for oxidation of this monodeuterated compound compared to normal isotopic composition benzyl alcohol was not determined precisely. However, the rate constants for the two reactions are roughly the same, and we anticipate that the ratio of rate constants $\left(\mathrm{k}_{\mathrm{H}} / \mathrm{k}_{\mathrm{D}}\right)$ will be around 2 . The rate constants for oxidation of the benzyl alcohols by a tenfold excess of the $\mathrm{Ru}(\mathrm{IV})$ complex are roughly the same as both compounds contain $\mathrm{C}-\mathrm{H}$ bonds that react in preference to $\mathrm{C}$-D bonds. We noted that further oxidation of the ${ }^{1} \mathrm{H}$ - and ${ }^{2} \mathrm{H}$ benzaldehydes to benzoic acid shows a strong kinetic isotope effect.

An organic substrate with a single site for isotopic substitution appears to be needed for this demonstration, and we have prepared the monodeuterated derivatives of benzhydrol and secphenyl ethyl alcohol. As before, both compounds were prepared by reduction of benzophenone and acetophenone, respectively, with LAD in ether. Preliminary measurements of the rate constants [excess $\mathrm{Ru}(\mathrm{IV})$ ] indicates the kinetic isotope effect $\left(\mathrm{k}_{\mathrm{H}} / \mathrm{k}_{\mathrm{D}}\right)$ is greater than 25 . Although the kinetic isotope effect for oxidation of benzyhydrol is relatively high, the absolute rate constant for oxidation of the ${ }^{1} \mathrm{H}$-benzyhydrol by $\left[\mathrm{Ru}(\mathrm{lV})(\text { terpy)(bpy)O }]^{2+}\right.$ indicates this reaction is 
sluggish, apparently because of steric hindrance. Oxidation of set-phenyl ethyl alcohol by $\left[\mathrm{Ru}(\mathrm{IV})(\text { terpy)(bpy)O }]^{2+}\right.$ occurs with a rate constant comparable to that reported for oxidation by IMW@PY),(PY)OI ${ }^{2+}$ and is an attractive candidate for removal of tritium from water. Because of solubility considerations and the ability to remove the tritiated derivative from solution by ion exchange, we will begin an investigation of the sulfonic acid derivative of acetophenone as a reducible substrate.

Kinetic Isotope Effects for a Ru(VI) Oxidant. In earlier work, the preparation and properties of the four electron oxidant trans-[Ru(VI)(tpy)(O) $\left.)_{2}(\mathrm{~S})\right]^{2+}\left(\mathrm{S}=\mathrm{CH}_{3} \mathrm{CN}, \mathrm{H}_{2} \mathrm{O}\right)$ were described. We have examined the kinetics of oxidation of benzyl alcohol by this oxidant. There are two sequential redox steps in the first oxidation of $\mathrm{PhCH}_{2} \mathrm{OH}$ by $\mathrm{Ru}(\mathrm{VI})$ in $\mathrm{CH}_{3} \mathrm{CN}$ to give benzaldehyde, $\mathrm{PhCHO}$, and the $\mathrm{Ru}(\mathrm{IV})$ complex $\left[\mathrm{Ru}(\mathrm{IV})(\mathrm{tpy})(\mathrm{O})\left(\mathrm{NCCH}_{3}\right)_{2}\right]^{2+}$. This reaction occurs with $\left(\mathrm{k}_{\mathrm{H}} / \mathrm{k}_{\mathrm{D}}\right)=12$ for $\mathrm{PhCH}_{2} \mathrm{OH}$ compared with $\mathrm{PhCD}_{2} \mathrm{OH}$ at $25^{\circ} \mathrm{C}$. In the second step oxidation of $\mathrm{PhCH}_{2} \mathrm{OH}$ by $\mathrm{Ru}(\mathrm{IV})$ occurs also to give benzaldehyde but with $\mathrm{k}_{\mathrm{H}} / \mathrm{k}_{\mathrm{D}}=61$.

Redox Catalysts in Sol-Gels. We have developed procedures for confining $\left[\mathrm{Ru}(\mathrm{tpy})(\mathrm{bpy})\left(\mathrm{H}_{2} \mathrm{O}\right)\right]^{2+}$ in thin film silica sol-gel films on $\mathrm{In}_{2} \mathrm{O}_{3}(\mathrm{Sb})$ electrodes. The sol-gels are formed by hydrolysis of silicon alkoxides under acidic or basic conditions. The mild conditions employed allow the incorporation of dyes. A typical preparation involves forming a solution containing $1.7 \mathrm{~mL}$ ethanol, $0.6 \mathrm{~g}$ Triton $\mathrm{X}-100,0.1 \mathrm{~mL} \mathrm{HClO}_{4} 0.01 \mathrm{M}$, and $4.6 \mathrm{mg}$ $\left[\mathrm{Ru}(\mathrm{tpy})(\mathrm{bpy})\left(\mathrm{H}_{2} \mathrm{O}\right)\right]\left[\mathrm{ClO}_{4}\right]_{2}$. The gelation process is initiated by addition of $0.2 \mathrm{~mL}$ of TMOS (tetramethyl ortho silicate) with the solution spread onto ITO electrodes with air drying followed by drying in an oven 24 hours at $55^{\circ} \mathrm{C}$.

The mole ratio of Si to Ru was varied from 100 to 1000. Cyclic voltammetric measurements on the resulting thin film structure reveal the existence of both $\mathrm{Ru}(\mathrm{III} / \mathrm{II})$ and $\mathrm{Ru}(\mathrm{IV} / \mathrm{III})$ couples. The electrochemical response depends on several factors including the aging conditions of the film. The complex is slowly leached from the films by extended soaking of the electrode in solution. Spectroscopic investigation of the electrodes under potential control show that not all the complex incorporated in the sol-gel is active toward oxidation. A similar result was reported by De Armond (J. of Phys. Chem., 97: 2646, 1993) for $\left[\mathrm{Ru}(\mathrm{bpy})_{3}\right]^{2+}$ in a $\mathrm{SiO}_{2}$ sol-gel. The electrodes modified in this way are active toward the oxidation of organic substrates. For the oxidation of benzyl alcohol, the electrocatalytic response is limited by leaching of the complex to the external solution. Initial measurements reveal that this can be overcome by covalently attaching the catalyst to soluble polymer with incorporation of the polymer in the sol-gel matrix.

\section{Summary of Accomplishments}

- Work is in progress to measure the tritium kinetic isotope effect for oxidation of $\mathrm{TCO}_{2}^{-}$by $\left[\mathrm{Ru}(\mathrm{IV})(\mathrm{terpy})(\mathrm{bpy}) \mathrm{O}^{2+}\right.$.

- The sulfonic acid derivatives of the sec-phenyl ethyl alcohol/acetophenone redox couple, with $\left[\mathrm{Ru}(\mathrm{IV})(\text { terpy)(bpy)O }]^{2+}\right.$ as the oxidant, will be investigated as the organic substrate in a proof-of-principle demonstration of deuterium removal from water.

- A deuterium kinetic isotope effect of 61 has been observed for the second stage in the oxidation of benzyl alcohol by the Ru(VI) oxidant, trans-[Ru(VI)(tpy)(O) $\left.)_{2}(\mathrm{~S})\right]^{2+}\left(\mathrm{S}=\mathrm{CH}_{3} \mathrm{CN}\right)$. A manuscript describing this work has been submitted for publication. 
- Voltammetry has shown that the complex $\left[\mathrm{Ru}(\mathrm{tpy})(\mathrm{bpy})\left(\mathrm{H}_{2} \mathrm{O}\right)\right]^{2+}$ retains its redox activity after being immobilized in a sol-gel derived thin film on the surface of an electrode.

\section{Papers and Abstracts}

Lebeau, E. L. and T. J. Meyer. "Oxidation of Benzyl Alcohol by a Dioxo Complex of Ru(VI)." Submitted for publication. 